\title{
PROCEEDINGS
}

\section{THE ROYAL SOCIETY}

OF

\section{EDINBURGH.}

\author{
VOL. XVI.
}

NOVEMBER 1888 To JULY 1889.

E D I N B U RGH :

PRINTED BY NEILL AND COMPANY.

MDCCCXC. 


\section{CONTENTS.}

Election of Office-Bearers at the General Statutory Meeting, Monday, Nov. 26, 1888,

Chairman's Opening Address,

On Pseudalius alatus, Leuckart, collected by Mr Robert Gray in the Arctic Seas, and other species of the Genus. By Dr O. v. Linstow. Communicated by Dr John Murray. (With a Plate), . 15

Abstract of the Results of an Inquiry into the Causation of Asiatic Cholera. By Neil Macleod, M.D. Edin., and Walter J. Milles, F.R.C.S. Eng. Communicated by Dr Woodhead, . . . 18

Preliminary Remarks on the Homologies of the Mesenteries in Antipatharia and other Anthoza. By George Brook, Esq., Lecturer on Comparative Embryology in the University of Edinburgh, .

On Certain Bodies, apparently of Organic Origin, from a Quartzite Bed near Inveraray. By his Grace the Duke of Argyll, K.G., K.T.,

On the Virial Equation for Molecular Forces, being Part IV. of a Paper on the Foundations of the Kinetic Theory of Gases. By Professor Tait, . . . . . . .

Strophanthus hispidus: its Natural History, Chemistry, and Pharmacology. By Professor Thomas R. Fraser, M.D., . .

A New Type of Dimorphism found in certain Antipatharia. By George Brook, Esq., Lecturer on Comparative Embryology in the University of Edinburgh, . . . . . . .

The Change in the Thermoelectric Properties of Wood's Fusible Metal at its Melting Point. By Albert Campbell, Esq., B.A.,

Note on the Relation between the Mutual Distances of Five Points in Space. By Thomas Muir, IL.D., . . . . . 86

The Relation among Four Vectors. Note on Dr Muir's Paper. By

Professor Tait, 
The History and Theory of Heredity. By J. Arthur Thomson, Esq., M.A., .

On the Anatomy and Histology of Phreoryctes. By Frank E. Beddard, Esq., M.A., Prosector to the Zoological Society of London, Lecturer on Biology at the Medical School of Guy's Hospital,

Note on the Transformation of Ciliated and Stratified Squamous Epithelium as a result of the Application of Friction. By Dr John Berry Haycraft and E. W. Carlier, Esq., M.B., B.Se.,

Observations on the Metabolism of Man during Starvation. By Noël Paton, M.D., and Ralph Stockman, M.D., . . . .

A Method of Demonstrating the Presence of Uric Acid in the Contractile Vacuoles of some Lower Organisms. By Dr A. B. Griffiths, F.R.S. (Edin.), F.C.S. (Lond. and Paris), Member of the Physico-Chemical Society of St Petersburg, \&c., .

On Improvements in the Apparatus for Counting the Dust Particles in the Atmosphere. By John Aitken, Esq., Darroch. (With Four Plates),

The Prolonged Action of Sea-Water on Pure Natural Magnesium Silicates. By Alexander Johnstone, Esq., F.G.S.,

Deductive Evidence of a Uterine Nerve Centre, and of the Location of such in the Medulla Oblongata. By James Oliver, M.D., F.R.S.E., • . . . . . . . .

On the so-called "Liver" of Carcinus manas. By $\mathrm{Dr}$ A. B. Griffiths, F.R.S. (Edin.), F.C.S. (Lond. and Paris), Member of the Physico-Chemical Society of St Petersburg, \&c., . . . . 178

On the Air's Resistance to an Oscillating Body (its Influence on Time-Keepers). By Edward Sang, LL.D., . . . . 181

A Contribution to the Chromatology of the Bile. By John Berry Haycraft, M.D., D.Sc., and Harold Scofield, Esq., M.B., · 188

On the Identity of Hofmann's "Dibenzyl-Phosphine" with Oxide of Tribenzyl-Phosphine, and on some other Points connected with the Phosphorised Derivations of Benzyl. By. Professor Letts and R. F. Blake, Esq., Queen's College, Belfast, . 193

Differentiation of any (Scalar) Power of a Quaternion. By Alexander M'Aulay, Esq., Ormond College, Melbourne. Communicated by Professor Tait, . . . . . . 201

Note on Mr M'Aulay's Paper. By Professoe Tait, . . . . 205

Additional Remarks on the Virial of Molecular Force. By Professor Tait, . . . . . . . . . 206

The Theory of Determinants in the Historical Order of its Development. By Thomas Muir, M.A., LL.D., . . . . 207 
The Electrotonic Variation with Strong Polarising Currents. By George N. Stewart, D.Sc., Owens College, Manchester, .

Notice of Fundamental Tables in Trigonometry and Astronomy, arranged according to the Decimal Division of the Quadrant. By Edward Sang, LL.D.,

On the Relation among the Line, Surface, and Volume Integrals.

By Professor Tait, .

The Development of Diarthrodial Joints in Birds and Mammals. By David Hepburn, M.B., M.R.C.S. (Eng.), Senior Demonstrator of Anatomy, University of Edinburgh. Communicated by Professor Sir W. Turner,

Electrification of Air by Flame. By Sir William Thomson, 262 On the Placentation of the Halicore Dugong. By Professor Sir William Turner,

On the Geographical Distribution of some Tropical Diseases, and their Relation to Physical Phenomena. By R. W. Felkin, M.D., F.R.G.S., Lecturer on Diseases of the Tropics and Climatology, Edinburgh Medical School. (With I6 Plates), . . . 266

Quaternion Note on a Geometrical Problem. By Professor Tait, . 315

The Solubility of Carbonate of Lime in Fresh and Sea Water. By W. S. Anderson, Esq., Chemist at Marine Station, Granton, . 319

Secretion of Carbonate of Lime by Animals. Part II. By Robert Irvine, F.C.S., and G. Sims Woodhead, M.D.,

Theoretical Description of a New "Azinuth Diagram." By Captain Patrick Weir. Communicated by Sir William Thomson,

Note on Captain Weir's Paper. By Professor Tait, .

On the Coagulation of Egg and Serum Albumen, Vitellin, and Serum Globulin, by Heat. By John Berry Haycraft, M.D., D.Sc., and C. W. Duggan, M.B., . . . . . . . 361

Some New Points in Connection with Muscle Contraction. By Alexander James, M.D., . $\quad$. $\quad$ • $\quad$ • . 385

The Theory of Determinants in the Historical Order of its Development. By Thomas Muir, M.A., LL.D., . 389

A Revision of the Genus Coscinodiscus and some Allied Genera. By John Rattray, M.A., B.Sc., F.R.S.E. (With Three Plates), . 449

Molecular Constitution of Matter. By Sir William Thomson, . 693

Continued Observations on the Progression and Rotation of Bivalve Molluscs, and of detached Ciliated Portions of them. By D. M'Alpine, Esq. Communicated by Dr Sims Woodhead. (With Two Plates), 
Pharmacological Action. PAGE 743 Dr Thomas R. Fraser, . . . .

The Theory of Determinants in the Historical Order of its Development. By Thømas Muir, M.A., LL.D., . . . 748

On the Scalar Relations connecting Six Vectors . By the Rev. M. M. U. Wilkinson. Communicated by Professor Tait,

Report on Atmospheric Circulation, based on the Observations made on Board H.M:S. "Challenger," 1873-76. . By Alexander Buchan, LL.D.,

On the Stomach of the Narwhal (Monodon monoceros). By G. Sims Woodhead, M.D:, and Robert W. Gray, Esq. (With Four Plates),

Meetings of the Royal Society-Session 1888-89, . . . $\quad .807$

Donations to the Library, . . . . . . . . . . . 823

Index, . $\quad . \quad . \quad . \quad . \quad . \quad . \quad . \quad . \quad 841$ 